\title{
Synthesis, Characterisation, Crystal Structure, and Antimicrobial and Larvicidal Studies of $\left[\mathrm{Cu}\left(2,2^{\prime} \text {-bipy }\right)_{2} \mathrm{SO}_{4}\right] \cdot 3 \mathrm{CH}_{4} \mathrm{~N}_{2} \mathrm{O} \cdot 2 \mathrm{H}_{2} \mathrm{O}$
}

\author{
Sundaramurthy Santha Lakshmi and Srinivasan Samundeeswari \\ Department of Chemistry, DKM College for Women (Autonomous), Vellore 632 001, India \\ Correspondence should be addressed to Sundaramurthy Santha Lakshmi; santhalakshmi_s@yahoo.com
}

Received 21 August 2014; Accepted 27 November 2014

Academic Editor: Alfonso Castiñeiras

Copyright (C) 2015 S. Santha Lakshmi and S. Samundeeswari. This is an open access article distributed under the Creative Commons Attribution License, which permits unrestricted use, distribution, and reproduction in any medium, provided the original work is properly cited.

\begin{abstract}
A pentacoordinated mononuclear copper(II) complex, namely, bis(2,2'-bipyridine)sulphatecopper(II) urea trisolvate dihydrate, has been synthesised and characterised by molar conductance and UV-Vis and FTIR spectra. The structure of the complex was unambiguously confirmed by single crystal XRD. The complex crystallizes in monoclinic system, space group $C 2 / c$, with the values $a=20.155(4), b=20.858(4)$, and $c=14.425(3) \AA ; \alpha=90.00^{\circ}, \beta=96.51^{\circ}$, and $\gamma=90.00^{\circ} ; V=6025(2) \AA^{3}$ and $Z=8$. The Cu(II) ion is coordinated to four nitrogen atoms of two bidentate $2,2^{\prime}$-bipyridine ligands (bipy) and by one oxygen atom of the sulphate group and displays distorted trigonal bipyramidal geometry. The crystal packing is stabilized by inter- and intramolecular hydrogen bonding. The $\mathrm{Cu}(\mathrm{II})$ complex was screened for antimicrobial activity against Staphylococcus aureus, Escherichia coli, Klebsiella pneumonia, Aspergillus niger, Aspergillus flavus, and Candida albicans. Larvicidal activity of the synthesized copper(II) complex was carried out against larvae of Culex quinquefasciatus and Anopheles subpictus.
\end{abstract}

\section{Introduction}

The coordination chemistry of copper has been connected to diverse fields like industry, electronics, and medicine. Adducts of metal complexes act as very good model systems for investigations in the area of molecular recognition and molecular association $[1,2]$. Due to the interaction of the metal ions with Lewis bases, the metal complexes increase their coordination number, which takes place by either intermolecular association or adduct formation with the solvents or ligands possessing good ligating ability [3]. The ligands with various donor features show different types of molecular associations.

Aromatic nitrogen heterocycles are important class of ligands in coordination chemistry. Among them bidentate chelating agent like $2,2^{\prime}$-bipyridine and its analogues readily form stable complexes with most of the transition metal ions and have been extensively used due to their applications in various fields like catalysis, preparative coordination chemistry, electrochemistry, and biochemistry [4].
Human beings suffer extensively due to insects especially mosquito bites. Some mosquitoes are vectors for diseases, which means that they can transmit diseases from one human or animal to another. According to the World Health Organization, mosquito bites result in the deaths of more than 1 million people every year. The majority of these deaths are due to malaria. The World Health Organization estimates that between 300 and 500 million cases of malaria occur each year and a child dies from malaria every 30 seconds. Recent estimates indicate that $90 \%$ of the $1.5-3$ million deaths due to malaria occur in Africa [5] and over one-third of the 146 million people infected with lymphatic filariasis are from this continent [6]. Mosquitoes are the major vector of transmitting harmful diseases such as malaria, yellow fever, filariasis, and dengue fever. Culex quinquefasciatus, the southern house mosquito, transmits diseases such as lymphatic filariasis and malaria $[7,8]$. Hence, we made an attempt to study the larvicidal activity of the $\mathrm{Cu}$ (II) complex. Herein, we report the synthesis and spectroscopic and crystal 
structure of $\mathrm{Cu}(\mathrm{II})$ complex and its antibacterial, antifungal, and larvicidal activities.

\section{Experimental}

2.1. Materials and Physical Measurements. All the reagents and chemicals were procured from commercial sources and were used without purification. $\mathrm{CuSO}_{4} \cdot 5 \mathrm{H}_{2} \mathrm{O}$ was purchased from S.D. Fine Chemicals, Mumbai (India), and 2,2' bipyridine was purchased from Central Drug House (P) Ltd., Mumbai (India).

Molar conductance of the complex was measured in DMSO $\left(10^{-3} \mathrm{M}\right)$ solution using a direct digital conductivity meter. FTIR spectra of solid complex were recorded using $\mathrm{KBr}$ pellet in the region of $4000-400 \mathrm{~cm}^{-1}$ on AVATAR 330 spectrophotometer. A UV-Vis spectrum of the complex was recorded in the region of 200-800 $\mathrm{nm}$ using a Hitachi U-2800 spectrophotometer in DMSO.

2.2. Synthesis. An aqueous solution of copper(II) sulphate $(1 \mathrm{mmol}, 0.253 \mathrm{~g})$ was added to an aqueous solution of urea $(1 \mathrm{mmol}, 0.061 \mathrm{~g})$ and the solution was stirred for $30 \mathrm{~min}$ at $343 \mathrm{~K}$. Then, an ethanolic solution of $2,2^{\prime}$-bipyridine $(1 \mathrm{mmol}$, $0.158 \mathrm{~g}$ ) was added in drops and the solution was stirred for additional $3 \mathrm{~h}$ at the same temperature. The resultant bluecoloured solution was filtered and kept at room temperature. Blue-coloured crystals obtained by slow evaporation of the mother liquor were collected and dried.

2.3. X-Ray Crystallography. For the determination of crystal structure, single crystal of the complex was used for data collection on Bruker single crystal Kappa Apex II diffractometer. The crystal of the $\mathrm{Cu}$ (II) complex with the crystal size of 0.23 $\times 0.19 \times 0.15 \mathrm{~mm}^{3}$ was mounted on a glass fibre and used for data collection. Crystal data were collected using graphite monochromatized Mo-K $\alpha$ radiation $(\lambda=0.71073 \AA)$.

The structure was solved by direct method using SHELXS-97 and refined by full-matrix least-squares techniques against $F^{2}$ using SHELXL-97 $[9,10]$. All the nonhydrogen atoms were refined anisotropically. A summary of pertinent crystal data along with further details of structure determination and refinement are given in Table 1.

2.4. Antimicrobial Activity. The $\mathrm{Cu}(\mathrm{II})$ complex was screened for antimicrobial activity against Escherichia coli, Staphylococcus aureus, and Klebsiella pneumoniae by the well-agar diffusion method [11]. Stock solutions were prepared by dissolving $1 \mathrm{mg}$ of the sample per $\mathrm{mL}$ of DMSO solution. In a typical procedure, a well was made on the agar medium inoculated with the microorganism. The well was filled with the test solution using a micropipette and the plate was incubated at $35^{\circ} \mathrm{C}$ for $24 \mathrm{~h}$. The antifungal activity was also evaluated against Aspergillus flavus, Aspergillus niger, and Candida albicans. DMSO was used as negative control whereas ampicillin and polymyxin B sulphate were used as positive control against bacteria and fungi, respectively. The antimicrobial activity was evaluated by measuring the zone of inhibition in $\mathrm{mm}$.
TABLE 1: Crystal data and structure refinement for the complex $\left.\mathrm{Cu}\left(2,2^{\prime} \text {-bipy }\right)_{2} \mathrm{SO}_{4}\right] \cdot 3 \mathrm{CH}_{4} \mathrm{~N}_{2} \mathrm{O} \cdot 2 \mathrm{H}_{2} \mathrm{O}$.

\begin{tabular}{|c|c|}
\hline Empirical formula & $\mathrm{C}_{23} \mathrm{H}_{32} \mathrm{CuN}_{10} \mathrm{O}_{9} \mathrm{~S}$ \\
\hline Formula weight & 688.19 \\
\hline Temperature/K & $293(2)$ \\
\hline Crystal system & Monoclinic \\
\hline Space group & $\mathrm{C} 2 / \mathrm{c}$ \\
\hline$a / \AA$ & $20.155(4)$ \\
\hline$b / \AA$ & $20.858(4)$ \\
\hline$c / \AA ̊$ & $14.425(3)$ \\
\hline$\alpha /^{\circ}$ & 90.00 \\
\hline$\beta 1^{\circ}$ & $96.51(3)$ \\
\hline$\gamma /^{\circ}$ & 90.00 \\
\hline Volume $/ \AA^{3}$ & $6025(2)$ \\
\hline$Z$ & 8 \\
\hline$\rho_{\text {calc }} \mathrm{mg} / \mathrm{mm}^{3}$ & 1.517 \\
\hline $\mathrm{m} / \mathrm{mm}^{-1}$ & 0.861 \\
\hline$F(000)$ & 2856.0 \\
\hline Crystal size $/ \mathrm{mm}^{3}$ & $0.23 \times 0.19 \times 0.15$ \\
\hline $2 \Theta$ range for data collection & 3.84 to $56.62^{\circ}$ \\
\hline Index ranges & $\begin{array}{c}-25 \leq h \leq 19,-27 \leq k \leq 27, \text { and } \\
-19 \leq l \leq 12\end{array}$ \\
\hline Reflections collected & 21903 \\
\hline Independent reflections & $6624[R(\mathrm{int})=0.0310]$ \\
\hline Data/restraints/parameters & $6624 / 0 / 461$ \\
\hline Goodness of fit on $F^{2}$ & 1.031 \\
\hline Final $R$ indexes $[I>2 \sigma(I)]$ & $R_{1}=0.0360, w R_{2}=0.0878$ \\
\hline Final $R$ indexes [all data] & $R_{1}=0.0642, w R_{2}=0.0990$ \\
\hline Largest diff. peak/hole/e $\AA^{-3}$ & $0.32 /-0.34$ \\
\hline
\end{tabular}

2.5. Larvicidal Activity. The egg and egg rafts of Culex quinquefasciatus and Anopheles subpictus were procured from Zonal Entomological Research Centre, Vellore, Tamil Nadu, to start the colony and larvae were kept in plastic trays containing dechlorinated water. They were maintained at $27 \pm$ $2^{\circ} \mathrm{C}$ and $75-85 \%$ relative humidity under $14: 10$ light and dark cycles. Larvae were fed with powdered nutrient broth once in a day. Pupae were transferred from the trays into plastic bottles containing dechlorinated water where the adults emerged. After 4 days the hatched larvae turned into larvae in early fourth stage and were subjected to experimentation.

Larvicidal Bioassay. From the stock solution, 1000 ppm was prepared with dechlorinated tap water. The larvicidal activity was assessed $[12,13]$ using the procedure reported by Rahuman et al. [14]. For the bioassay test, larvae were taken in three batches of 20 in $200 \mathrm{~mL}$ of water and $1.0 \mathrm{~mL}$ of the $\mathrm{Cu}$ (II) complex. The control was set up with polysorbate 80 . The numbers of dead larvae were counted after $24 \mathrm{~h}$ of exposure, and the percentage mortality was reported from the average of triplicates. The experimental media, in which $100 \%$ mortality of larvae occurs alone, were selected for doseresponse bioassay. 
Dose-Response Bioassay. From the stock solution, different concentrations ranging from 5 to $500 \mathrm{mg} / \mathrm{L}$ were prepared. Based on the preliminary screening results, $\mathrm{Cu}$ (II) complex was subjected to dose-response bioassay against the larvae of Culex quinquefasciatus and Anopheles subpictus. The numbers of dead larvae were counted after $24 \mathrm{~h}$ of exposure, and the percentage mortality was reported from the average of triplicates [15].

\section{Results and Discussion}

The copper(II) complex is found to be stable at room temperature and soluble in ethanol, DMF, and DMSO. The lower molar conductivity value of $5 \Omega^{-1} \mathrm{~cm}^{2} \mathrm{~mol}^{-1}$ in DMSO supports the nonelectrolytic nature of the complex [16].

3.1. Spectroscopic Characterisation. The UV-Vis spectra of the $\mathrm{Cu}$ (II) complex displayed $\pi \rightarrow \pi^{*}$ transition of benzene ring at $283 \mathrm{~nm}$ and the band which appeared at $388 \mathrm{~nm}$ corresponds to $n \rightarrow \pi^{*}$ transition. The broad band which appeared at $635 \mathrm{~nm}$ corresponds to d-d transition of the copper(II) ion.

The FTIR spectra of the Cu(II) complex show a broad and intense band at $3388 \mathrm{~cm}^{-1}$, due to strong hydrogen bonds including urea and water molecules $[17,18]$. The $\mathrm{C}=\mathrm{N}$ stretching frequency of $2,2^{\prime}$-bipyridine appears at $1603 \mathrm{~cm}^{-1}$. The free sulphate ion is highly symmetric. Upon coordination, the symmetry of the sulphate group is lowered. Medium bands which appeared at 485 and $990 \mathrm{~cm}^{-1}$ correspond to $v_{1}$ and $v_{2}$ modes of vibrations, respectively. The monodentate sulphate ion displayed sharp bands at 1097 and $1124 \mathrm{~cm}^{-1}$ which correspond to $v_{3}$ the symmetric stretching and the bands which appeared at $612 \mathrm{~cm}^{-1}$ correspond to $v_{4}$ the asymmetric bending vibrations. $\mathrm{Cu}-\mathrm{O}$ and $\mathrm{Cu}-\mathrm{N}$ linkages are confirmed by weak bands observed at 412 and $553 \mathrm{~cm}^{-1}$, respectively [19].

3.2. Crystal Structure. The selected bond lengths and bond angles of the synthesized $\mathrm{Cu}(\mathrm{II})$ complex are listed in Table 2. An ORTEP [20] view of the $\mathrm{Cu}$ (II) complex along with the atom numbering scheme is depicted in Figure 1. The complex crystallizes in monoclinic system, space group $C 2 / c$.

In the present work, we made an attempt to synthesize an adduct of urea and 2,2' -bipyridine with copper(II) ion. But urea molecules remain uncoordinated with the metal ion. The complex crystallizes with three urea molecules and two water molecules which remain uncoordinated with the $\mathrm{Cu}$ (II) ion. The $\mathrm{Cu}$ (II) ion is pentacoordinated via the nitrogen atoms of $2,2^{\prime}$-bipyridine and oxygen atom of sulphate group. Five-coordination is common for $\mathrm{Cu}$ (II) with either trigonal bipyramidal (tbp) or square pyramidal geometry. For distinguishing between tbp and square pyramidal geometry in case of five-coordinated metal complexes, Addison et al. [21] have introduced index of trigonality $\tau$ (where $\tau=(\beta-\alpha) / 60$, in which $\alpha$ and $\beta$ are the two largest coordination angles). In general, $\tau=0$ for an ideal square pyramidal and $\tau=1$ for ideal tbp geometry. In the present case, by taking N2-Cu-N4 as $\beta\left(174.42^{\circ}\right)$ and $\mathrm{N} 3-\mathrm{Cu}-\mathrm{O} 1$ as $\alpha\left(136.04^{\circ}\right)$, the $\tau$ value is
TABLE 2: Selected bond lengths $[\AA]$ and bond angles [deg.] for the complex $\left[\mathrm{Cu}\left(2,2^{\prime} \text {-bipy }\right)_{2} \mathrm{SO}_{4}\right] \cdot 3 \mathrm{CH}_{4} \mathrm{~N}_{2} \mathrm{O} \cdot 2 \mathrm{H}_{2} \mathrm{O}$.

\begin{tabular}{lccc}
\hline \multicolumn{5}{c}{ Bond lengths } \\
\hline $\mathrm{Cu}-\mathrm{N} 1$ & $2.1210(18)$ & $\mathrm{N} 1-\mathrm{C} 5$ & $1.346(3)$ \\
$\mathrm{Cu}-\mathrm{N} 2$ & $1.9775(17)$ & $\mathrm{N} 1-\mathrm{C} 1$ & $1.341(3)$ \\
$\mathrm{Cu}-\mathrm{N} 3$ & $2.0697(19)$ & $\mathrm{N} 3-\mathrm{C} 11$ & $1.341(3)$ \\
$\mathrm{Cu}-\mathrm{N} 4$ & $1.9694(17)$ & $\mathrm{N} 4-\mathrm{C} 16$ & $1.343(3)$ \\
$\mathrm{Cu}-\mathrm{O} 1$ & $2.0307(16)$ & $\mathrm{N} 4-\mathrm{C} 20$ & $1.339(3)$ \\
$\mathrm{O} 1-\mathrm{S} 1$ & $1.4930(16)$ & $\mathrm{N} 3-\mathrm{C} 15$ & $1.347(3)$ \\
$\mathrm{N} 2-\mathrm{C} 10$ & $1.340(3)$ & $\mathrm{C} 15-\mathrm{C} 16$ & $1.473(3)$ \\
$\mathrm{N} 2-\mathrm{C} 6$ & $1.342(3)$ & $\mathrm{C} 5-\mathrm{C} 6$ & $1.478(3)$ \\
\hline \multicolumn{5}{c}{ Bond angles } \\
\hline $\mathrm{N} 2-\mathrm{Cu}-\mathrm{N} 1$ & $79.42(7)$ & $\mathrm{N} 4-\mathrm{Cu}-\mathrm{N} 2$ & $174.42(7)$ \\
$\mathrm{N} 2-\mathrm{Cu}-\mathrm{N} 3$ & $100.72(8)$ & $\mathrm{N} 4-\mathrm{Cu}-\mathrm{N} 3$ & $80.62(8)$ \\
$\mathrm{N} 2-\mathrm{Cu}-\mathrm{O} 1$ & $90.06(7)$ & $\mathrm{N} 4-\mathrm{Cu}-\mathrm{O} 1$ & $92.69(7)$ \\
$\mathrm{N} 3-\mathrm{Cu}-\mathrm{N} 1$ & $107.84(7)$ & $\mathrm{O} 1-\mathrm{Cu}-\mathrm{N} 1$ & $116.03(7)$ \\
$\mathrm{N} 4-\mathrm{Cu}-\mathrm{N} 1$ & $95.00(7)$ & $\mathrm{O} 1-\mathrm{Cu}-\mathrm{N} 3$ & $136.04(7)$ \\
\hline
\end{tabular}

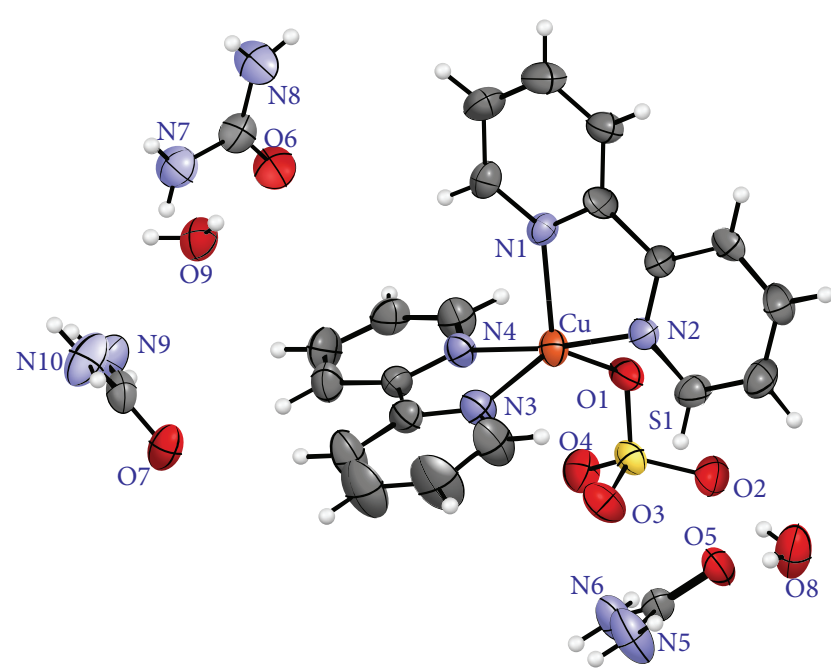

Figure 1: An ORTEP view of $\mathrm{Cu}(\mathrm{II})$ complex with the numbering scheme.

calculated as 0.64 . This value is intermediate between square pyramidal and tbp and the $\tau$ value is slightly closer to the later one (ideal tau $=1$ ) $[22,23]$. This indicates that the complex exhibits distorted tbp geometry and the distortion may be due to the presence of bulky groups like $2,2^{\prime}$-bipyridine.

The basal plane is occupied by $\mathrm{N} 1-\mathrm{Cu}, \mathrm{N} 3-\mathrm{Cu}$, and O1-Cu with the bond distances 2.121(2), 2.070(2), and 2.031(2) $\AA$, respectively. The equatorial plane is occupied by $\mathrm{N} 2-\mathrm{Cu}$ and N4-Cu with the bond distances being 1.977(2) and 1.969(2) $\AA$, respectively. The bond angle N2-Cu-N4 is $174.42(7)^{\circ}$. Using the bond angles N1-Cu-N3 $\left(107.84(7)^{\circ}\right)$, $\mathrm{N} 3-\mathrm{Cu}-\mathrm{O} 1\left(136.04(7)^{\circ}\right)$, and O1-Cu-N1 $\left(116.03(6)^{\circ}\right)$, the sum of the bond angles around $\mathrm{Cu}(\mathrm{II})$ is calculated as $359.91^{\circ}$ which is very close to $360^{\circ}$. This confirms the presence of $\mathrm{Cu}$ (II) ion with very slight deviation from the basal plane. Three molecules of urea and two molecules of water remain uncoordinated with the $\mathrm{Cu}(\mathrm{II})$ ion, whereas these involve 
TABLE 3: Hydrogen bond lengths $(\AA)$ and bond angles $\left(^{\circ}\right)$ for $\left[\mathrm{Cu}\left(2,2^{\prime}-\text { bipy }\right)_{2} \mathrm{SO}_{4}\right] \cdot 3 \mathrm{CH}_{4} \mathrm{~N}_{2} \mathrm{O} \cdot 2 \mathrm{H}_{2} \mathrm{O}$.

\begin{tabular}{|c|c|c|c|c|}
\hline $\mathrm{D}-\mathrm{H} \cdots \mathrm{A}$ & $d(\mathrm{D}-\mathrm{H})$ & $d(\mathrm{H} \cdots \mathrm{A})$ & $d(\mathrm{D} \cdots \mathrm{A})$ & $\angle \mathrm{DHA}$ \\
\hline C17-H17 ‥ O & 0.930 & 2.47 & 3.393 & 171 \\
\hline $\mathrm{C} 18-\mathrm{H} 18 \cdots \mathrm{O} 9$ & 0.930 & 2.55 & 3.238 & 131 \\
\hline $\mathrm{C} 14-\mathrm{H} 14 \cdots \mathrm{O} 7$ & 0.929 & 2.45 & 3.374 & 172 \\
\hline $\mathrm{C} 10-\mathrm{H} 10 \cdots \mathrm{O} 5$ & 0.929 & 2.60 & 3.230 & 135 \\
\hline C7-H7 $\cdots$ O1 & 0.929 & 32.41 & 3.234 & 148 \\
\hline N6-H6B-O3 ${ }^{\mathrm{a}}$ & 0.79 & 2.13 & 2.919 & 142 \\
\hline $\mathrm{O} 8-\mathrm{H} 8 \mathrm{Y} \cdots \mathrm{O} 3$ & 0.912 & 2.78 & 3.440 & 129 \\
\hline O8-H8Y $\cdots \mathrm{S} 1$ & 0.912 & 2.87 & 3.739 & 158 \\
\hline $\mathrm{O} 8-\mathrm{H} 8 \mathrm{Y} \cdots \mathrm{O} 2$ & 0.912 & 1.99 & 2.898 & 172 \\
\hline O9-H9X $\cdots$ O6 & 0.796 & 2.026 & 2.807 & 166 \\
\hline $\mathrm{N} 7-\mathrm{H} 7 \mathrm{~B} \cdots \mathrm{O} 2^{\mathrm{b}}$ & 0.82 & 2.16 & 2.974 & $172(3)$ \\
\hline $\mathrm{N} 8-\mathrm{H} 8 \mathrm{~A} \cdots \mathrm{O} 4^{\mathrm{b}}$ & 0.80 & 2.06 & 2.848 & 167 \\
\hline $\mathrm{N} 8-\mathrm{H} 8 \mathrm{~B} \cdots \mathrm{O} 4^{\mathrm{b}}$ & 0.80 & 2.06 & 2.848 & 173 \\
\hline
\end{tabular}

Symmetry codes: (a) $1-x, y, 1 / 2-z$; (b) $x, 1-y, 1 / 2+z$.

TABle 4: Antimicrobial data of $\mathrm{Cu}(\mathrm{II})$ complex.

\begin{tabular}{|c|c|c|c|c|c|c|}
\hline Compound & S. aureus & E. coli & K. pneumoniae & A. niger & A. flavus & C. albicans \\
\hline $\mathrm{Cu}(\mathrm{II})$ complex & 22 & 16 & 12 & $<10$ & $<10$ & $<10$ \\
\hline Bipy & $<10$ & 14 & 11 & $<10$ & $<10$ & $<10$ \\
\hline Urea & $<10$ & $<10$ & $<10$ & $<10$ & $<10$ & $<10$ \\
\hline Ampicillin & 30 & 16 & 33 & & & \\
\hline Polymyxin B sulphate & & & & 11 & 11 & 11 \\
\hline
\end{tabular}

TABLE 5: $\mathrm{LC}_{50}, \mathrm{LC}_{90}$ and other statistical analyses of $\mathrm{Cu}(\mathrm{II})$ complex against the larvae of Culex quinquefasciatus and Anopheles subpictus.

\begin{tabular}{lccccc}
\hline Species & $\mathrm{LC}_{50} \pm \mathrm{SE}(\mathrm{ppm})$ & $\mathrm{UCL}-\mathrm{LCL}$ & $\mathrm{LC}_{90} \pm \mathrm{SE}(\mathrm{ppm})$ & $\mathrm{UCL}-\mathrm{LCL}$ & $\chi^{2}(\mathrm{df}=4)$ \\
\hline Culex quinquefasciatus & $58.21 \pm 4.21$ & $66.46-49.95$ & $285.70 \pm 34.18$ & $352.70-218.70$ & 8.31 \\
Anopheles subpictus & $28.95 \pm 2.22$ & $33.312-2.60$ & $168.05 \pm 23.56$ & $360.79-245.61$ & 8.88 \\
\hline
\end{tabular}

$\mathrm{LC}_{50}$ : lethal concentration that kills $50 \%$ of the exposed larvae.

$\mathrm{LC}_{90}$ : lethal concentration that kills $90 \%$ of the exposed larvae.

UCL: upper confidence limit; LCL: lower confidence limit; $\chi^{2}$ : chi-square.

df: degree of freedom significant at $P<0.05$ level.

intermolecular hydrogen bonding. The crystal packing is mainly stabilized by inter- and intramolecular hydrogen bonding. These interactions are depicted in Figure 2 and the corresponding data are given in Table 3.

3.3. Antimicrobial Activity. The zone of inhibition exhibited by $\mathrm{Cu}(\mathrm{II})$ complex against the bacteria and fungi under study is summarized in Table 4 . The results revealed that the $\mathrm{Cu}$ (II) complex is found to be resistant to the fungi under study, whereas it shows moderate activity against the bacteria showing zone of inhibition $22 \mathrm{~mm}, 16 \mathrm{~mm}$, and $12 \mathrm{~mm}$ against $S$. aureus, E. coli, and $K$. pneumoniae, respectively. The antibacterial activity exhibited by the $\mathrm{Cu}$ (II) complex is comparatively greater than the corresponding chelating agents like bipy and urea.

3.4. Larvicidal Activity. The results of larvicidal activity of the $\mathrm{Cu}(\mathrm{II})$ complex (Table 5) showed higher mortality value

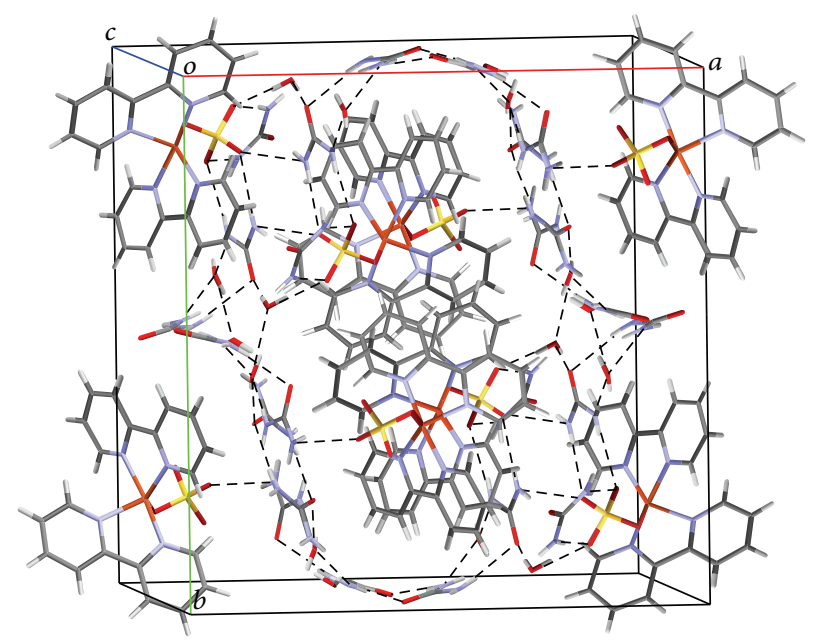

FIgURE 2: The molecular packing diagram of $\mathrm{Cu}(\mathrm{II})$ complex. Hydrogen bonds are shown as dashes. 
of $85 \pm 2.44 \%$ and $61 \pm 2.74 \%$ against the larvae Culex quinquefasciatus and Anopheles subpictus, respectively.

The average larval mortality data were subjected to probit analysis for calculating $\mathrm{LC}_{50}, \mathrm{LC}_{90}$ and other statistics at $95 \%$ fiducial limits of upper confidence limit and lower confidence limit, and chi-square values were calculated. Results with $P<0.05$ were considered to be statistically significant.

\section{Conclusions}

The titled complex was characterized by UV-Vis, FTIR, and $\mathrm{X}$-ray crystallography. The structural analysis revealed that the $\mathrm{Cu}$ (II) complex exhibited distorted trigonal bipyramidal geometry around $\mathrm{Cu}(\mathrm{II})$ ion. The antimicrobial studies suggested that the $\mathrm{Cu}$ (II) complex exhibited moderate antibacterial activity against $S$. aureus, E. coli, and $K$. pneumoniae and resistance to the fungi under investigation. The $\mathrm{Cu}(\mathrm{II})$ complex exhibited good larvicidal activity against Culex quinquefasciatus and Anopheles subpictus.

\section{Conflict of Interests}

The authors declare that there is no conflict of interests regarding the publication of this paper.

\section{Acknowledgments}

The authors thank the management and the Department of Chemistry, DKM College for Women, Vellore, Tamil Nadu, India, for the constant support and encouragement.

\section{References}

[1] E. Meštrović, D.-K. Bučar, I. Halasz, and V. Stilinović, "The first adduct of bis(1,3-diphenyl-1,3-propanedionato)oxovanadium(IV)," Acta Crystallographica Section E: Structure Reports Online, vol. 60, no. 12, pp. m1920-m1922, 2004.

[2] E. W. Ainscough, A. M. Brodie, W. A. Denny, G. J. Finlay, and J. D. Ranford, "Nitrogen, sulfur and oxygen donor adducts with copper(II) complexes of antitumor 2-formylpyridinethiosemicarbazone analogs: physicochemical and cytotoxic studies," Journal of Inorganic Biochemistry, vol. 70, no. 3-4, pp. 175-185, 1998.

[3] S. B. Kalia, G. Kaushal, and Priyanka, "Synthesis and characterization of pyridine adducts of some transition metal 4-methylpiperazine-1-carbodithioic acid complexes," Himachal Pradesh University Journal, pp. 1-8, 2011.

[4] B. S. Kulkarni, D. Mishra, and S. Pal, "Role of substituents on the reactivity and electron density profile of diimine ligands: a density functional theory based study," Journal of Chemical Sciences, vol. 125, no. 5, pp. 1247-1258, 2013.

[5] Africa Malaria Report, World Health Organization, Geneva, Switzerland, 2002.

[6] E. J. Muturi, C. M. Mbogo, Z. W. Ng'ang'a et al., "Relationship between malaria and filariasis transmission indices in an endemic area along the Kenyan Coast," Journal of Vector Borne Diseases, vol. 43, no. 2, pp. 77-83, 2006.

[7] L. Regis, S. B. da Silva, and M. A. V. Melo-Santos, "The use of bacterial larvicides in mosquito and black fly control programmes in Brazil," Memorias do Instituto Oswaldo Cruz, vol. 95, supplement 1, pp. 207-210, 2000.

[8] V. K. Agrawal and V. K. Sashindran, "Lymphatic filariasis in India: problems, challenges and new initiatives," Medical Journal Armed Forces India, vol. 62, no. 4, pp. 359-362, 2006.

[9] G. M. Sheldrick, SHELXS-97: Program for the Crystal Structure Refinement, University of Göttingen, Göttingen, Germany, 1997.

[10] G. M. Sheldrick, SHELXL-97: Program for the Solution of Crystal Structures, University of Göttingen, Göttingen, Germany, 1997.

[11] NCCLS, Method for Dilution Antimicrobial Susceptibility Test for Bacteria that Grow Aerobically, approved standards, National Committee for Clinical Standards, Villanova, Pa, USA, 5th edition, 2000.

[12] WHO, CTD/WHO PES/IC/96.1, p. 69, 1996.

[13] R. Suganthi, S. Santha Lakshmi, G. Kannappan, and A. Abdul Rahuman, "Synthesis, spectroscopic characterisation, antimicrobial and larvicidal studies of some transition metal complexes derived from tetradentate Schiff base ligand," Journal of Pharmacy Research, vol. 4, no. 12, pp. 4574-4576, 2011.

[14] A. A. Rahuman, G. Gopalakrishnan, B. S. Ghouse, S. Arumugam, and B. Himalayan, "Effect of Feronia limonia on mosquito larvae," Fitoterapia, vol. 71, no. 5, pp. 553-555, 2000.

[15] C. Kamaraj, A. Bagavan, G. Elango et al., "Larvicidal activity of medicinal plant extracts against Anopheles subpictus \& Culex tritaeniorhynchus," Indian Journal of Medical Research, vol. 134, no. 7, pp. 101-106, 2011.

[16] W. J. Geary, "The use of conductivity measurements in organic solvents for the characterisation of coordination compounds," Coordination Chemistry Reviews, vol. 7, no. 1, pp. 81-122, 1971.

[17] G. M. de Lima, D. C. Menezes, C. A. Cavalcanti et al., "Synthesis, characterisation and biological aspects of copper(II) dithiocarbamate complexes, $\left[\mathrm{CuS}_{2} \mathrm{CNR}\left(\mathrm{CH}_{2} \mathrm{CH}_{2} \mathrm{OH}\right)_{2}\right],(\mathrm{R}=$ $\mathrm{Me}, \mathrm{Et}, \mathrm{Pr}$ and $\mathrm{CH}_{2} \mathrm{CH}_{2} \mathrm{OH}$ )," Journal of Molecular Structure, vol. 988, no. 1-3, pp. 1-8, 2011.

[18] O. Z. Yeşilel, H. Paşaoǧlu, G. Kaştaş, H. Ölmez, and O. Büyükgüngör, "Synthesis, crystal structure, spectral and thermal studies of a new organic-inorganic hybrid cobalt(II) complex of $2,2^{\prime}$-bipyridine and nitrate with squarate," Zeitschrift für Naturforschung-Section B Journal of Chemical Sciences, vol. 61, no. 10, pp. 1249-1253, 2006.

[19] K. Nakamoto, Infrared and Raman Spectra of Inorganic and Coordination Compounds, John Wiley \& Sons, New York, NY, USA, 4th edition, 1986.

[20] C. K. Johnson, “ORTEP," Report ORNL 3794, Oak Ridge National Laboratory, Oak Ridge, Tenn, USA, 1996.

[21] A. W. Addison, T. N. Rao, J. Reedijk, J. Van Rijn, and G. C. Verschoor, "Synthesis, structure, and spectroscopic properties of copper(II) compounds containing nitrogen-sulphur donor ligands; the crystal and molecular structure of aqua[1,7-bis $(N$ methylbenzimidazol-2' -yl)-2,6-dithiaheptane]copper(II) perchlorate," Journal of the Chemical Society, Dalton Transactions, no. 7, pp. 1349-1356, 1984.

[22] K. Diwan, B. Singh, S. K. Singh, M.G. B. Drew, and N. Singh, "Facile in situ copper(II) mediated C-S bond activation transforming dithiocarbimate to carbamate and thiocarbamate generating $\mathrm{Cu}(\mathrm{II})$ and $\mathrm{Cu}(\mathrm{I})$ complexes," The International Journal for Inorganic, Organometallic and Bioinorganic Chemistry, Dalton Transactions, vol. 41, no. 2, pp. 367-369, 2012.

[23] M. Gupta, P. Mathur, and R. J. Butcher, "Synthesis, crystal structure, spectral studies, and catechol oxidase activity of trigonal bipyramidal $\mathrm{Cu}$ (II) complexes derived from a tetradentate diamide bisbenzimidazole ligand," Inorganic Chemistry, vol. 40, no. 5, pp. 878-885, 2001. 

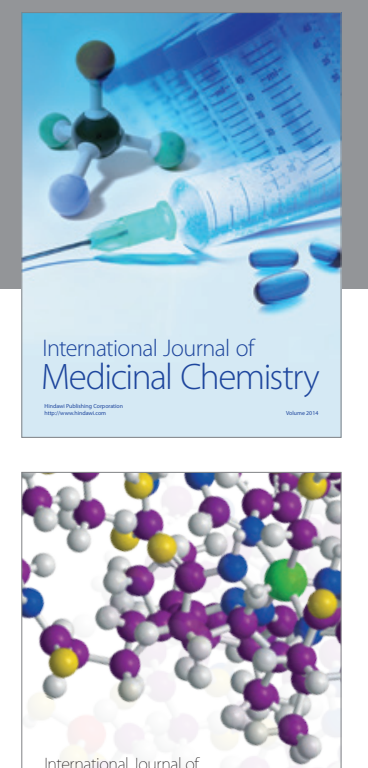

\section{Carbohydrate} Chemistry

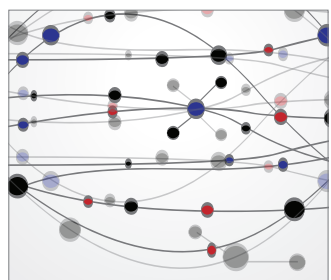

The Scientific World Journal
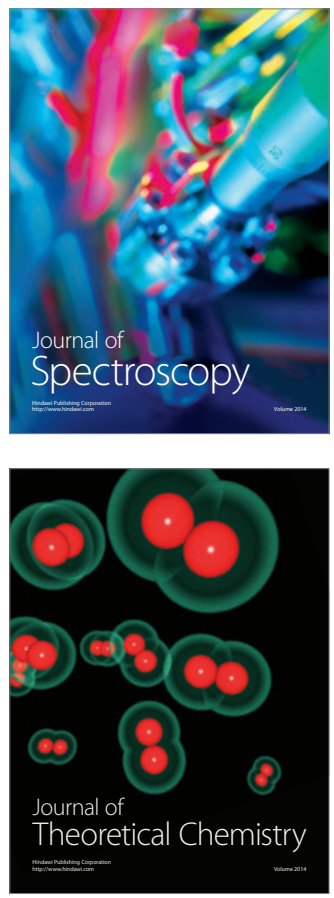
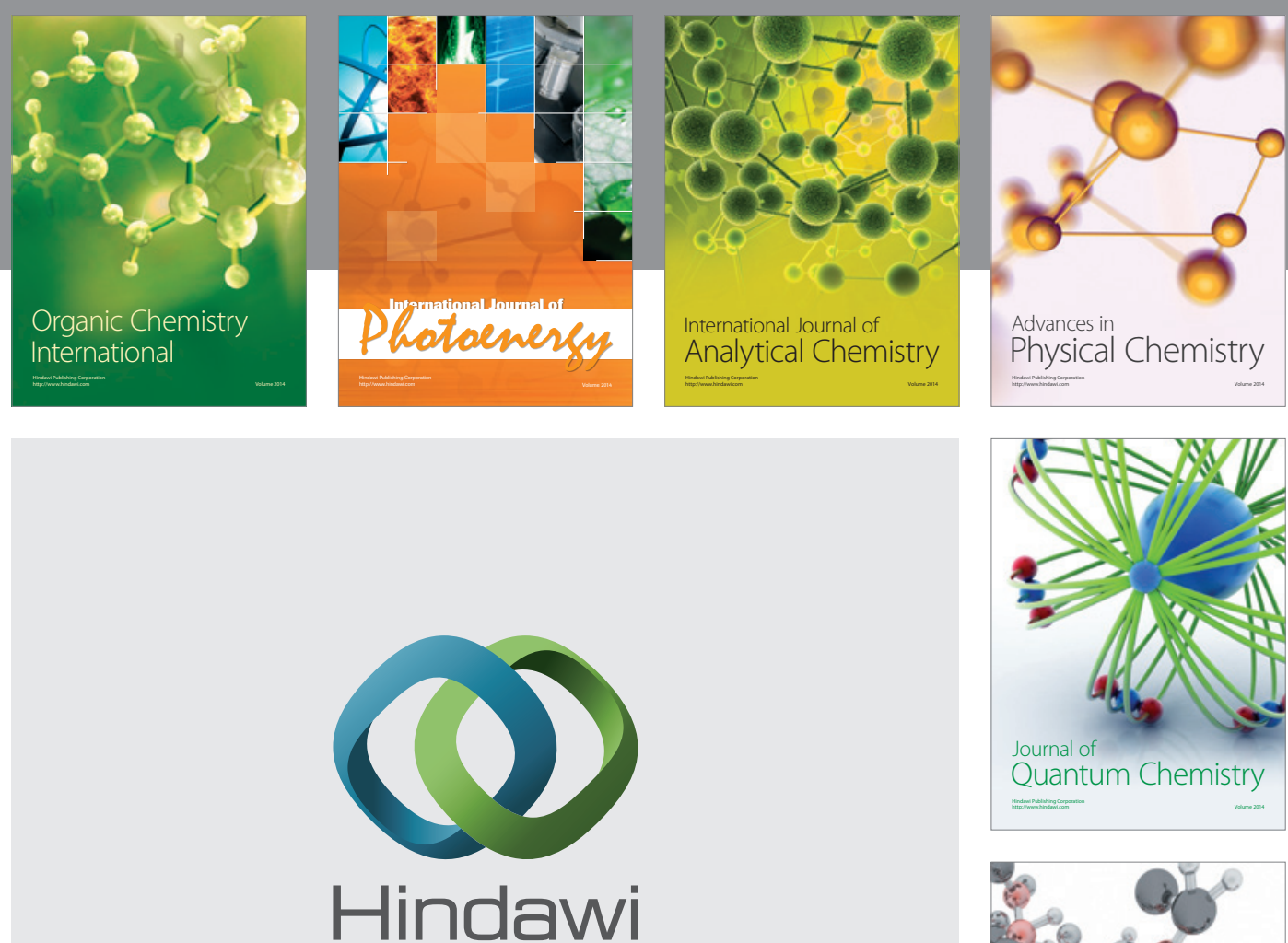

Submit your manuscripts at

http://www.hindawi.com

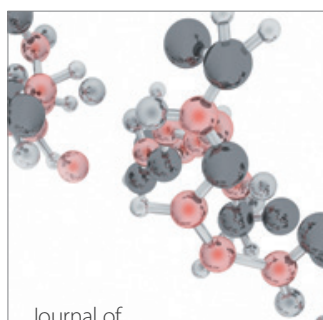

Analytical Methods

in Chemistry

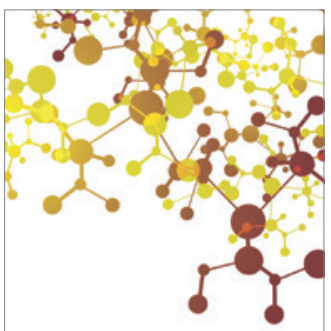

Journal of

Applied Chemistry

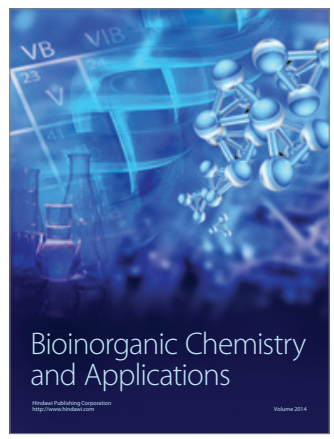

Inorganic Chemistry
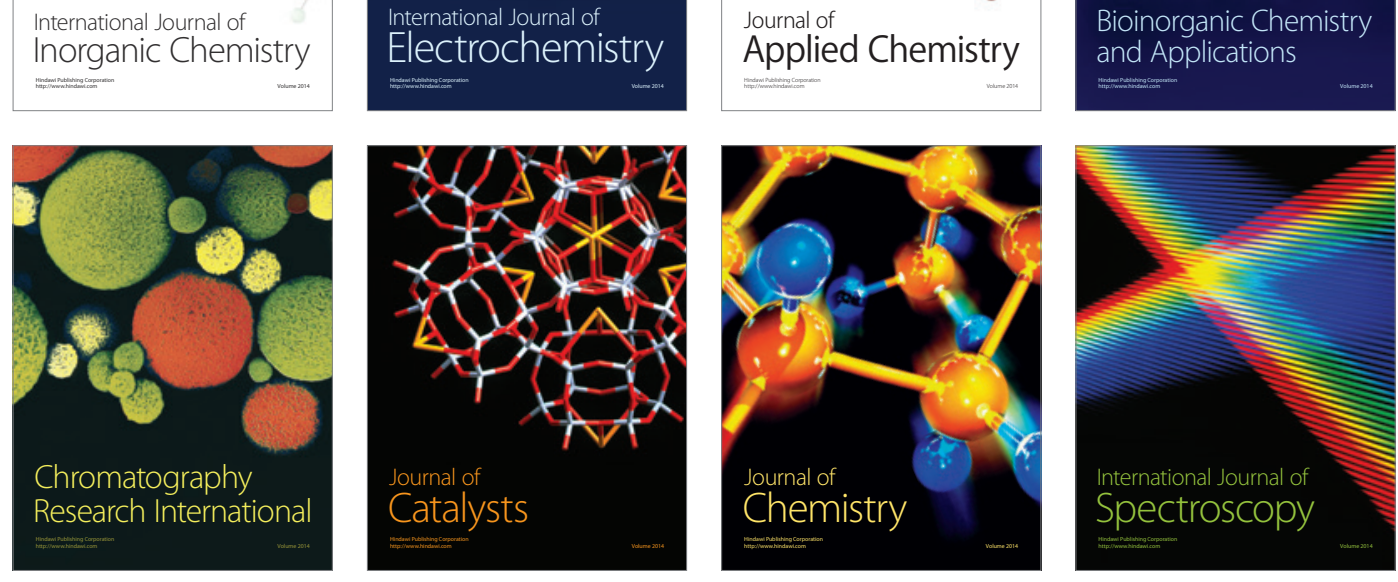